\title{
DE BELASTING NAAR HET INKOMEN TE AMSTERDAm.
}

De burgemeester heeft in eene der laatste zittingen van den gemeenteraad de commissie tot onderzoek der ingekomen bezwaarschriften in zake de inkomstenbelasting dank betuigd voor de vele moeite, die zij zich in het belang der gemeente heeft getroost. Zoo ooit, dan was thans deze dankbetuiging geene ijdele pligtpleging, maar wel verdiend. Te oordeelen naar de agenda der gemeenteraads zittingen - bij gebreke van volledige openbaarheid der kohieren tevens het eenige authentieke document, dat voor belastingschuldigen en niet-belastingschuldigen eenig licht verspreidt over de werking der belasting - zijn niet minder dan eenige duizenden bezwaarschriften door de commissie onderzocht.

Bij een ieder, die het wel meent met de gemeente, heeft dit feit een pijnlijken indruk achtergelaten. Daaruit is toch afteleideu, dat de opgaven van een groot aantal belastingschuldigen volgens de meening van Burg. en Weth. weinig vertrouwen verdienden, dat de aanslag van het dagelijksch bestuur door de belanghebbenden weinig juist werd geacht, en dat de belasting, althans de wijze van uitvoering veel ontevredenheid heeft verwekt. Het laatste feit is bedroevend; de bemoeijingen van het dagelijksch bestuur en der verschillende commissien hadden meer waardering verdiend. Doch het eerstgenoemde is nog meer te betreuren. De inkomstenbelasting is volgens velen eene heffing, waardoor de openbare lasten 't meest gelijkmatig tusschen de burgers worden verdeeld en althans in dit opzigt eene voortreffelijke belasting. Is het thans echter gebleken dat de inkomsten der ingezetenen niet met juistheid zijn vast te stellen, dat de maatstaf van verdeeling, welke de inkomstenbelasting heet in zich te sluiten, niet aanwezig of ten minste niet voor toepassing vatbaar is, dan is het tevens aanneembaar dat de inkomstenbelasting feitelijk eene onlillijke 
belasting is, waarloor noodwendig de een te zwaar wordt belast, de ander een deel van zijn andeel in de openbare lasten ontloopt en zelfs zij, die eene juiste opgave van hun inkomen verstrekken, meer of minder dan het door hen verschuldigde zullen betalen, naar gelang hunne medelurgers te hoog of te laag zijn aangeslagen, dan zou de belasting in geen enkel opzigt aanbeveling verdienen, op den duur onhourlbaar zijn, en $\Lambda$ msterdam wederom voor het moeijelijke feit zijn gesteld van haar belastingstelsel te moeten herzien.

Minder zwartgalligen zullen welligt beweren dat de treurige uitkomst niet zoozeer te wijten is aan do belasting, als aan de wijze, waarop zij hier ter stede geregeld werd. Zij zullen niet betwisten, dat de aangiften van belastingschuldigen dikwerf weinig vertrouwen verdienen, en de aanslag van overheidswege bij gebreke van nauwkeurige gegevens steeds eenigermate willekeurig moet zijn. Deze bezwaren, dus zullen zij vervolgen, waren bekend, de ervaring, elders verkregen, heeft ze reeds lang aangewezen. Men kan zelfs zeggen dat zij nimmer geheel zullen zijn weg te nemen, maar de mate, waarin zij zich doen gevoelen, hangt af van de wijze waarop de belasting geregeld is. De wetgever dient er voor te waken, dat geene bepalingen worden opgenomen, die de ontduiking in de hand werken, en geene controle te verzuimen, die met de vrijheid der burgers bestaanbaar is. Beide voorwaarden worden door de Amsterdamsche verordening echter niet nagekomen.

Ik ben geneigd dit oordeel te onderschrijven. De vraag of de inkomstenbelasting eene goede belasting is, is thans niet aan de orde. Deze vraag is in het vorig jaar beslist en de voorstanders van destijds zullen met regt beweren dat op een zoo diep ingrijpend besluit niet dadelijk mag worden teruggekomen, dat de ervaring van één jaar onvoldoende is om het beginsel te veroordeelen en hoogstens ten nutte is te maken om de toepassing te verbeteren. De inkomstenbelasting heeft grove gebreken, maar welke belasting heeft die niet? Vooral in zake van belastingen geldt het spreekwoord, dat elke verandering nog geene verbetering is. $\mathrm{Er}$ is geene moeijelijker vraag in de geheele belastingleer dan deze, welke belasting de beste of beter gezegd de minst slechte kan worden genoemd. In het algemeen is deze vraag zelfs voor geen afdoend antwoord vatbaar, veel hangt af van de omstandigheden, van de uitgaven, die te dekken zijn. Waar het eene gemeente geldt, is laarbij niet te vergeten, dat haar slechts eene beperkte keuze is 
voorhehouden, terwijl Amsterdam hovendien nog dit eigenaardige heeft, dat de uitgaven in betrekkelijk korten tijd aanzienlijk zijn gerezen en woldra nog belangrijk zullen vermeordoren. $\left(^{*}\right)$

Amsterlam is niet op éćne lijn te stellen met de overige gemeenten des lands. Hetgeen in twee ecuwen niet heeft plaats gevonden, is in de laatste vijftien jaren geschied. De stad heeft zich ten derde male uitgebreil. Nieuwe, groote wijken zijn verrezen, en de oudo hebhen monige verandering ondergaan. Daarbij is cen nieuwe weg natr zee geopend, die ons, zoo de verhetering van den Rijnvaart nict to lang op zich laat wachten, de hoop gecft dat de bronnen van stoffelijke welvaart allengs wederom milder zullen vloejen, maar daartegen de verpligting oplegt te voorzien in kostbare inrigtingen voor den handel. In één woord Amsterdam is een niouw tijdperk ingetreden. Maar wie de lusten heeft, heeft de lasten. Deze zijn aanmerkelijk toegenomen en hebben hun hoogste standpunt nog niet bereikt. Vele onderwerpen van gemeentezorg eischen nieuwe uitgaven, de leening, die voor de leur staat, zal een evenredig hedrag voor rente en aflossing vorderen, terwijl de inkomsten zullen verminderen, zoodra de drie millioen gulden, thans op het grootboek der nationale schuld ingeschreven,

(*) De vraag, welke belastingen voor genconten atabeveling verdienen, trekt in bet bujtenlaud niet minder de algemeene andacht dan hier te lande, vooral nadat de Pruissische regerinir een ontwerp vau wet op de gemeentebelastingen aan den Lauddag had aangeboden eu de Verein fïr Socialpolitik "die Commualstenerfrage" op de agenda harer laatste bijeenkonst bad geplatst. Wij danken aan deze omstandigheid cen deel, bevatteude niet miuder dan tien adviezen en rajporten over de verschillende gemecntelijke belastingstelseis in hei Duitsche rijk: die Communalsteuerfraye, zehn Gutachten und Berifhte, veröftentlioht vom V'erein fïr Socialpolitik, voorts een praealvies van dew bekenden Berlijnschen hoogleeraar Ad. Wayner, in de bijeenkomst van het congres uitgebragt: die Communalsteuerfrage. Ausarbeitung eines Reforats in Ferein fitr Socialpolitik. Mil einem Nachwort, etc. en ten slotte een belangrijk debat, gehoulen in deze vergadering, waarvan een stenographisch verslag door de Vereeniging is nitgegeven en een resumé vau de hand van prof. Held wordt gevouden in de vierde alleveriug vau het Jahrbuch für Gesetzgebung, Fervoaltung und Volkswirthschaft im Deutschen Reich, 1877. Naar aanleidiog van eerstgenoemde adviezen verschenen verder: die Besteutung der Gemeindon. Finanzzoissenschafiliche Erörierungen von Mr. R. Friedberg (Berlin Puttkammer \& Mühlbrecht) en die Gemeindebestouerung und deren Reform von 1 r. Leon ritter von Bilinski (Leipzig Duncker \& Humblot, 1878.) Een aantal zeer belangrijke bijzonderheden over gemeentebelastingen zijn te vinden in die progressive Linkommensteutr im Staats und Gemeinde-Hanshalt. Gutachten ïber Personalbestenterng anf Feranlassung des Vereins fiir Socialpolitik von Fr. J. Neumsnn, (Leipzig Duncker \& Humblot) een werkje, rijk aan foiten. 
aan de Kanaalmaatsehappij zijn uitgekeerd en de op'rengst der leening van 1874 geheel zal zijn verwerkt.

Onder deze omstandigheden was het een kloek besluit van den gemeenteraad eene belasting intevoeren, die, welke gebreken zij ook moge bezitten, althans dit voordeel heeft, dat zij in staat is eene aanzienlijke opbrengst te verzekeren. Het was een besluit, waarbij de raad stilzwijgend verklaarde vertrouwen te stellen in de burgerij, dat deze haar pligt zou beseffen, en bereid zou zijn eerlijk de offers te brengen, die van haar gevorderd werden, dat zij juiste opgaven zou doen van hare inkomsten, naar waarheid zou vorklaren: zooveel zijn mijne inkomsten en naar gelang daarvan zal ik bijdragen.

De uitvoering van dit besluit was moeijelijk. Doch nadat het eenmaal genomen was, nadat in beginsel was vastgesteld, dat de gemeentelasten, voor zooverre zij niet uit andere middelen zijn te bestrijden, naar mate van ieders inkomen onder de burgers dienen te worden verdeeld, nadat men verklaard had overtuigd te zijn, dat zulks billijk was, had men wel gedaan het besluit geheel te nemen. Vreesde men dat de burgerij weinig geneigd zou zijn opgave van hare inkomsten te doen, en in verhouding daarvan te betalen, men had het daarheen behooren te leiden, dat deze weerzin overwomnen werd, en de ingezetenen de overtuiging erlangden dat de belasting billijk en noodzakelijk was. Maar in dit opzigt is naar mijne meening veel verzuimd. In stede van streng naar het zuiver inkomen te. belasten, en naauwkeurig te bepalen wat daaronder is te verstaan, werd het beginsel niet scherp geformuleerd en een aantal afwijkingen toegelaten, die even zoovele wegen openden om de belasting te ontduiken. Aan behoorlijke contrôle werd naauwelijks gedacht. Zelfs waar de gemeentewet het middel aan de hand gaf, was men ongenegen hetzelve toe te passen. En zoo werd hetgeen in beginsel was aangenomeu, bij de uitvoering wederom voor een groot deel afgebroken.

De eerste rraag, die bij eene inkomstenbelasting beslist dient te zijn, is wat onder inkomen is te verstaan? Oppervlakkig schijnt het antwoord gemakkelijk te geven. Inkomen, zullen velen zeggen, is datgene, wat ik kan verteren, zonder te verarmen. Ieder regtgeaard burger, die zijne verteringen naar zijn inkomen rigt, neemt dien maatstaf aan. Hij zal van zijne inkomsten aftrekken hetgeen tot instandhouding van zijn kapitaal is uitgegeven en hetgeen aan anderen behoort, b. v. rente van geleend geld, en het saldo als 
zuiver inkomen beschouwen. Intusschen is onder de geleerden wel eens versehil van meening geweest. De mensch kan niet arbeiden, zonder zich te voeden, te kleeden, eene woning te bezitten, in één woord in zijne levensbehoeften te voorzien. Om de zuivere opbrengst van een kapitaal te leeren kennen, trekt gij de kosten van onderhoud van de bruto-opbrengst af. Om de zuivere opbrengst van den arbeid te berekenen, moet gij dus, zoo zeggen sommigen, de onderhoudskosten van den arbeider in rekening brengen. Het onderhoud was noodig, opdat hij kunne arbeiden, de kosten daarvan zijjn kosten van voortbrenging. Geen zuiver nationaal inkomen, of inkomen van eene klasse of persoon is aanwezig, zoolang niet datgene is gedekt, wat een ieder noodig heeft om zijn arbeid te kunnen verrigten.

Zij, die aldus leerden, zịn geslagen. Zij hebben zelfs menig hard woord te verduren gehad. Gij verwart, dus zeide men hun, inkomen met ondernemerswinst. $\left({ }^{*}\right)$ Er bestaat eigenlijk geen ruw of zuiver inkomen, hetgeen inkomen is, is steeds zuiver. Er bestaat ruwe opbrengst, ruwe ontvangsten, maar al hetgeen gij ontvangt, is daarom nog geen inkomen. Welk winkelier zal zijne dagelijksche ontvangsten als inkomen beschouwen? Slechts de winst of het loon kan als zoodanig gelden, en dit is het inkomen; wat gij voor uw onderhoud kunt aanwenden. Waren hiervan nog uw onderhoudskosten af te trekken, dan moet gij eerst bewijzen dat gij leeft en eet om voort te brengen en niet voortbrengt om te leven, dat zooals een duitsch economist zeide, de houthakker zich voedt om hout te kunnen hakken, in stede van het hout te hakken om in zijne levensbehoeften te voorzien. En al zouden alle geleerden dit laatste leeren, zij, die eene belasting naar het inkomen voorstaan, mogen die leer niet huldigen, want het zoogenaamde vrije inkomen $(\dagger)$, dat is hetgeen overblijft nadat in het noodige onderhoud is voorzien, is zoo gering dat eene belasting, welke dit overschot van inkomsten tot grondslag had, eene zeer schrale opbrengst zou sehenken. Onder inkomen en onder zuiver inkomen is dus niet anders te verstaan, dan hetgeen iemand verteren kan zonder te verarmen.

De Amsterdamsche wetgever deelt in het algemeen deze meening,

(*) Hermann, staatswissenschaftliche Uutersuchungen pag. 324. Sehmoller, die Lehre rom Einkommen in ihrem Zusammenhang mit den Grundprincipien der Steuerlehre in het Zeitschrift für die Gesammte Staatswissenschaft. Tubingen 1863, pag. 1.

(t) Roscher, die Grundlagen der Nationaloekonomie ed. 1869. I. 145. 
maar de wijze, waarop hij het begrip van inkomen hepaalde, was weinig geschikt den belastingschuldigen, daarvan een juist denkbeeld te verschaffen. In stede van eene scherpe definitie geeft de verordening in art. 7 eene weinig duidelijke omschrijving van hetgeen in let algemeen onder inkomen is te verstaan, benevens eenige regelen, dic bij de toepassing dezer bepaling zijn in acht te nemen, terwijl tot nadere verduidelijking bij een afzonderlijk besluit lijzondere regelmn zijn vastgesteld.

Is het steeds bedenkelijk één begrip bij twee verschillende besluiten te formuleeren, waarvan het eene het andere moet aanvullen, maar ook ligt een weinig daarvan afwijkt, vooral blijkt dit hier, mu de verordening zelve voor verschillende uitlegging vatbaar is, en de "bijzondere regelen" niet in den vorm eener verordening werden gegeven, niet behoorlijk werden afgekondigd, en niet door den Koning bekrachtigd. Het gevolg daarvan is dat zij voor den belastingschuldige niet verbindend zijn, en hij zich aan de verordening kan houden, zonder op de bjjzondere regelen eenig acht te slaan, hetgeen to oordeelen, naar de klagten, welke nu en dan werden vernomen, niet zelden is geschied.

„Onder zuiver inkomen, dus luidt art. 7 , wordt in het algemeen verstaan de som van alles, wat in geld of bij eigen gebruik en genot van vruchten, in geldswaarde te berekenen, jaarlijks verkregen wordt:

10 uit onroerende of roerende zaken;

20 uit arheid, ambten, bedieningen, betrekkingen, wachtgelden en pensioenen;

30 uit renten en winsten van beroepen, bedrijven en ondernemingen, van welken aard ook;

40 uit elken anderen hoofde, krachtens welk regt en onder welke benaming ook;

na aftrek van hetgeen door de belastingschuldigen tot verkrijging, rerzekering of behoud dezer voordeclen is besteed geworden en van hetgeen volgens de wet of testamentaire bepaling, onafhankelijk van den wil des belastingschuldige is uitgegeven,

terwijl volgens litt. $d$ niet als inkomen worden aangemerkt alle toevallige baten, uit loterijen en dergelijken, erfenissen, schenkingen en legaten verkregen, en

volgens art. 10 , van het bedrag der belasting mag worden afgetrokken 5 ten honderd voor één inwonend minderjarig eigen of aangehuwd kind of kleinkind, en bovendien 3 ten honderd voor elk zoodanig kind boven dat getal, 
De in den aanhef gregeven definitie is zoo vaag, dat zelfs Ricardo $\left(^{*}\right)$, de vader der zoo even bestreden leer, daarmede genoegen zou hebben kunnen nemen. Het is veroorloofd af te trekken hetgeen tot verkrijging, verzekering of behoud dezer voordeelen is besteed. Hieronder kan des gewenscht alles worden begrepen, zelfs zonder den woorden geweld aan te doen, het onderhoud van den arbeider. Ik zeg niet, dat zulks de bedoeling van de verordening is, ik waag het zelfs niet te onderstellen, dat de belastingschuldigen het beproefd hebben de bepaling in dien geest op te vatten. Maar evenmin aarzel ik het te betwijfelen dat in vele gevallen, waar slechts de minste onzekerhcid bestond over hetgeen al of niet onder dezo woorden is te verstaan, de belastingschuldigen ze niet ten hunne nadeele hebben uitgelegd en daaraan nu en dan eene beteekenis hebben gegeven, die met het begrip van inkomen onbestaanbaar is. Zoo is hot zeer wel mogelijk dat door den een de premie van levensverzekering is afgetrokken, door den ander niet alleen de rente, maar de geheele annuiteit eener hypothecaire schuld, opgonomen tot aankoop van een onroerend goed, is in mindering gebragt. Men zal het een en het ander ongeoorloofd noemen. Volkomen waar, doch wie waarborgt bij de moeijelijkheid om de juistheid der aangiften nategaan dat zulks naar aanleiding van art. 7 niet is geschied en zoo het plaats vond, werd hersteld. Het hoofddoel van den wetgever behoort te zijn geene aanleiding te geven tot onjuiste opgaven, want de ontdekking daarvan is zeer moeijelijk en het herstel nog onzekerder. Nadat eenmaal hetgeen tot het credit van het inkomen behoort, uitvoerig was uiteengezet, ware het beter geweest ook hetgeen in mindering mag worden gebragt, in de verordening duidelijker to omschrijven. Verordeningen van andere gemeenten, bv. die van Arnhem zoude bij eene oventueele herziening in dit opzigt tot voorbeeld kunnen dienen. Art. 6 dier laatste bv. zegt na uiteengezet te hebben wat onder inkomen is te verstaan, „na aftrek van :

a. de renten van verschuldigde kapitalen, voor welke de eigendommen van den belastingschuldige zijn bezwaard of verpand, of van welker bestaan voldoende bewijzen wordt overgelegd;

b. hetgeen door den belastingschuldige tot noodzakelijk onderhoud van zijne eigendommen is besteed;

c. uitgaande lijfrenten en andere periodieke uitkeeringen, krachtens

${ }^{*}$ Priuciples of political economy and taxation ch, XXVI. 
de wet of krachtens testamentaire bepaling verschuldigd, onafhankelijk van den wil des belastingschuldige;

d. grond-, dijk-, polder- en andere zakelijke lasten.

Hetgeen gedurende een dienstjaar is verkregen uit loterijen en dergelijken, uit erfenis, legaat of schenking, wordt niet als inkomen, maar als vermeerdering van kapitaal aangemerkt, zoodanig echter, dat alle periodiek terugkecrende baten en schenkingen tot onderhoud steeds als inkomen worden beschouwd." (*)

Ook deze bepaling is welligt niet boven elke bedenking, maar zij is ongetwijfeld cene veel verbeterde lezing van art. 7 der Amsterdamsche verordening. De laatste bv. veroorlooft af te trekken, hetgeen volgens de wet onaflankelijk van den wil des helastingschuldige is uitgegeven. Wat is hieronder te verstaan? Bedoeld schijnen hoofdzakelijk belastingen. Eenigen daarvan, zooals grond- polder en andere zakelijke lasten, zelfs de patentbelasting, in één woord alle lasten, die op een bijzonder goed of op een bedrijf rusten, kunnen als ongelden of kosten worden beschouwd, die in mindering van de bruto-opbrengst zijn te brengen, alvorens de zuivere renten of winsten kunnen worden vastgesteld. Nadat de verordening echter had bepaald, dat alle onkosten van de renten of winsten zijn aftetrekken, had het in rekening brengen van belastingen, voor zooverre het veroorloofd kon zijn, geen bijzonder verlof noodig gehad. Waar zij tot de exploitatiekosten behooren, spreekt het van zelven. Ieder koopman zal de patentbelasting onder de bedrijfsonkosten opnemen, ieder grondbezitter de grond- en andere lasten van de huur aftrekken en alleen het saldo als rente beschouwen. Maar ten aanzien der persoonlijke lasten, bv. de belasting op het personeel, voor zooverre niet als gevolg. van de uitoefening van een of ander bedrijf geheven en vooral van de gemeentebelasting zelve, geldt zulks niet. Deze behooren tot de huishoudelijke uitgaven en zijn evenals alle overige uitgaven van dien aard uit het inkomen te bestrijden. De bepaling der verordening is mitsdien deels overbodig, en overigens eene door niets geregtvaardigde afwijking van het beginsel, dat het inkomen de grondslag der belasting is.

Volgens al. $d$ van hetzelfde artikel kunnen voorts alle toevallige baten in mindering van het inkomen worden gebragt. De verordening voegt daarbij uit loterijen en dergelijken, erfezissen, schenkingen

(*) Deze verordening is te vinden in het werkje van $\mathrm{mr}, \mathrm{H}$. H. van Cappelle: de plaatselijke directe belasting naar het inkomen poor de gemeente Arnhem. 
en Tegaten. vrrhreyen, doch wees er verzekerd van, dat de belastingschuldigen aan deze nadere bepaling weinig aandacht hebben geschonken en den klemtoon hebben gelegd op alle touvallige baten. zich welligt verdedigende met te beweren dat het niet aanneembaar is, dat de wetgever een voorregt heeft willen verzekeren aan door spel of zonder inspanning verkrcgen voordeelen boven degenen, welke door arbeid zijn ontvangen.

De bepaling dankt haar ontstaan aan eene bij de beraadslaging over het ontwerp opgeworpen vraag of een prijs, gevallen op eene obligatie der Amsterdamsche premieleening als inkomen is te beschouwen. Men wenschte deze en dergelijke vragen beslist te zien. Superflua nocent is hier van volle toepassing. De gemeenteraad betrad een gevaarlijken weg door te verklaren wat geen inkomen is en staande de vergadering een daartoe strekkend artikel in de verordening in te lasschen. In het algemeen is bv, niet te bepalen of schenkingen en legaten inkomen dan wel kapitaal zijn te achten. Sismondi zeide reeds: la qualité du capital ou du revenu s attache à la persomue et non à l'objet échangé. (*) Men mag aannemen dat hetgeen geerfd wordt, zoowel door den erflater als door den erfgenaam als kapitaal is beschouwd en dus voor de belasting dit ook als zoodanig aanmerken. Maar indien datgene, wat iemand om niet geeft, wordt verleend en vooral ontvangen om als inkomen te dienen, zooals bv. een legaat van lijfrenten, en de meeste schenkingen, is er voor den fiscus zeer zeker geen reden zijn deel daarvan niet te eischen, hoe toevallig het ook moge geweest zijn, dat het legaat of de schenking geschiedde.

Vooral het woord toevallig heeft een zeer ongunstigen invloed uitgeoefend. Het is niet gelukkig gekozen. Zal het 't kenmerk zijn waaraan is te zien of iets inkomen dan wel kapitaalis? Wie zou het durven beweren, dat toevallige baten geen inkomen kunnen zijn? Of ontvangsten toevallig; wisselvallig, waarschijnlijk of zeker zijn, wat doet het ter zake voor de beslissing der vraag of zij tot het inkomen behooren. En daarbij, wie zal het beslissen onder welke categorie de ontvangst is te rangschikken? De belastingschuldige? Hij is geen onpartijdig regter en daar een zakelijke maatstaf voor zijne beoordeeling ontbreekt, daar alles afhangt van persoonlijke opvatting, kan hij onder de toevallige baten brengen, al wat hem goeddunkt. Betaalt Spanje de rente, het is mogelijk dat hij 't als eene toevallige bate beschouwt, ontvangt

(*) Nouveaux principes d'économie politique I. p. 90. II. p. 376. 
hij een dividend, eene gratificatie of tantième boven zịnn vast salaris, hij doet welligt wederom 't zelfde, geniet hij eene uitkecring van zijne ouders of vaste ondersteuning van anderen, hij zou zich daarbij nog op 't woord schenkingen kunnen beroepen, en ook van dit deel zijner inkomsten geen aangifte doen. Men meene niet dat dit alles slechts onderstellingen zijn, ontsproten aan de phantasie van den schrijver. Verre zij het van dien. Herhaaldelijk heb ik opgemerkt dat deze bepaling door de belastingschuldigen onjuist was opgevat. De commissie zou, wierd zij gehoord, waarschijnlijk hetzelfde getuigen en ook zij weet niet alles. Men kan gerust aannemen, dat een aantal vermeende toevallige baten aan het oog van het dagelijksch bestuur zijn ontsnapt en dat zoo alle bekende feiten waren verzameld, men wel veel had vergaard, maar nog geen denkbeeld had van hetgeen tengevolge van deze bepaling aan de gemeente is te kort gedaan.

Een bedenking van anderen aard, welligt nog gewigtiger wijl zij het beginsel raakt, is te maken tegen art. 10, waarbij hepaald wordt dat van het bedrag der belasting mag worlen afgetrokken 5 ten houderd voor één inwonend minderjarig eigen of ongehuwd kind of kleinkind en bovendien 3 ten honderd voor elk kind boven dat getal.

Zoodanige bepaling behoort $\mathrm{m}$. $\mathrm{i}$. in eene inkomstenhelasting niet te huis. Men zegt wel eens dat deze heffing onbillijk is, wijl zij geen acht slaat op de finantieele krachten der burgers, dat gelijkheid in zake van belasting beteekent gelijkheid van opoffering on dat eene billijke verdeeling van lasten niet te verkrijgen is, zoo niet gelet wordt op de verschillende mate van opoffering, die het een ieder kost de belasting te betalen. In Engeland is dikwerf hierop gewezen, hier te lande nog voor weinige jaren door $\mathrm{mr}$. Pierson, in de Gid's van Januarij 1871. Is deze meening gegrond, dan is het eigentlijk met de inkomstenhelasting gedaan, want zij is niet overeentebrengen met het beginsel, waarop deze heffing in de allereerste plaats rust, dat het billijk zou zijn naar het inkomen te belasten. Daarvoor valt intusschen wel het een en ander te zeggon. Een ieder rigt zijne uitgaven naar zijne verteringen. Deze bepalen op den duur de mate van goederen of diensten, waarover een ieder die geen verkwister is, ter vervulling zijner persoonlijke behoeften en van die zijner familie kan beschikken. Belastingen zijn bijdragen, die ieder burger, wijl hij burger is, verpligt is op te brengen om den staat mogelijk te maken datgene 
te verrigten, wat hij noodig acht. Een ieders belang is daarbij ongeveer gelijk (*), zoodat waar het bij het groote verschil tusschen de middelen der verschillende burgers onuitvoerbaar is van een ieder eene gelijke som te vorderen, 't als beginsel niet onbillijk schijnt het bedrag van ieders bijdrage te bepalen naar het aandeel dat hij in het maatschappelijk inkomen ontvangt, waarnaar hij noodwendig al zijne overige genietingen bepaalt. Is dit aandeel te gering, dan hapert het aan de verdeeling van het maatschappelijk inkomen, en zou deze zoo mogelijk te wijzigen zijn, maar de onbillijkheid te willen herstellen of verminderen door de belasting anders te verdeelen, schijnt een halve maatregel en niet consequent, is met twee maten meten en in zake van belasting onregtvaardig noemen, wat elders wordt toegelaten of niet anders mogelijk geacht.

Het is moeijelijk het belastingstelsel zoodanig in te rigten, dat een ieder naar het inkomen betaalt. Volkomen waar, doch dit heeft deze theorie gemeen met al hare zusters, niet 't minst met die der gelijkheid van opoffering. Allen zijn voor strenge toepassing niet vatbaar. Intusschen wij weten reeds veel, zoo wij weten wat volmaaktheid is, waarheen wij bij de regeling van het belastingstelsel het oog hebben te rigten.

Het vraagstuk der verdeeling van belastingen is hiermede op lange na niet opgelost. Dit zou een afzonderlijk onderzoek vereischen. Doch voldoende hoop ik te hebben duidelijk gemaakt, wat onder belasting naar het inkomen is te verstaan en dat zij, die deze wijze van belasting verdedigen, verpligt zijn zich ook met deze beschouwing te vereenigen. Herhaaldelijk is voorgesteld de theorie van gelijkheid van opoffering daarop te enten, een enkel maal is het beproefd, doch bijna nooit gelukt.

De reden is duidelijk uiteengezet in cen rapport eener commissie uit het Engelsche Lagerhuis, die in 1861 eene uitvoerige enquête daarover hield. „This tax, zoo eindigde het verslag, having now been made the subject of investigation before two committees and no proposal for its amendinent having been found satisfactory, your committee are brought to the conclusion that the objections, which are urged against it, are objectious to its nature and essence rather than to the particular shape, which has been given to it." ( $\dagger$ )

$\mathrm{Zij}$, die eene inkomsten-belasting voorstaan, zijn dus genoopt

(*) Vooral duidelijk anugewezeu door J Stuart Mill, in zijne priuc. of pol. ecou. V ch. II. \&2.

( $\dagger$ ) Reeds vroeger trachtte ik in dit tijdsclırift, jaargang 1872 pag. 415, dit in bijzonderbeden ann te wijzen, 
afstand te doen van alle ingenomenheid net do leer der gelijkheid van opoffering, want geven $z i j$ toe aan hetgeen deze leert, zij liepen gevaar het beginsel, waarop de inkomsten-belasting rust, te ondermijnen. $\mathrm{Zij}$ behoeven nict te vragen of de belastingschuldigen kinderloos zijn of kinderen bezitten, willen zij althans in de belasting geen element brengen, dat aan de juistheid, aan de regtvaardigheid van het hoofdbeginsel doet twijfelen en dit allengs zou vernietigen.

Laat men ééne uitzondering toe, ras zullen meerderen volgen. De raadscommissie aan wie de belasting haar onstaan te danken heeft, zeide reeds: indien naauwkeurig omschreven oorzaken kunnen worden genoemd, die met evenveel billijkheid als de talrijkheid van het gezin op eene vermindering der belasting aanspraak geven, zou de commissie die aanspraak gaarne erkend zien." Men liet na verder te gaan en naar dergelijke oorzaken een naauwkeurig onderzoek in te stellen. Had men dit gedaan, er waren genoeg gevonden. De een had gewezen op den ziekelijken toestand zijner vrouw, die hem tot buitengewone uitgaven verpligt, de ander had gevraagd te willen acht geven op den aard van zijn inkomen, dat wisselvallig, in elk geval slechts tijdelijk zou zijn. Zoo de billijkheid den doorslag had te geven, zou de laatste vooral regt hebben inwilliging van zijnen eisch te verlangen. Want ik waag het te betwijfelen of dat zoogenaamde "kindergeld" wel in billijkheid te vorderen is. Wat zoudt gij er van zeggen, zoo men u eene bijdrage vroeg voor de opvoeding van de kinderen van uw buurman, die een welgesteld man is? Gij zoudt antwoorden, dat het de pligt der ouders is hunne kinderen optevoeden, dat de wet zulks uitdrukkelijk bepaalt, welligt voegdet gij er bij, dat wierd van dit beginsel afgeweken, de grondslagen der hedendaagsche matschappij wierden ondermijnd, de hand gereikt aan hot communisme, in elk geval de grondbeginselen der bevolkingsleer miskend. Maar indien dit waar is, kan het dan billijk zijn ontheffing van belasting te verleenen in verhouding van het aantal kinderen, dat de belastingschuldigen bezitten? Wat den een wordt kwijtgescholden, heeft toch de andere te betalen. "Solelie Dinge bei der Steuerumlegung beruecksichtigen zu wollen, wäre, zooals Schmoller teregt zegt, nicht mehr Gerechtigkeit, sondern communistische Gleichmacherei. $\left({ }^{*}\right)$

De Amsterdamsche verordening is in dit opzigt zeer vrijgevig. Ontheffing wordt verleend voor inwonende eigen, aangehuwde of

(*) 1. cit. jag. 56 . 
kleinkinderen; dat de ouders van deze laatsten nog leven, dat zij zelven in het onderhoud van het kind kunnen voorzien of zelfs voorzien, doet niets ter zake. De grootvader, wiens kleinkind ten zijnent woont, ontvangt ontheffing van een deel, terwijl de vader, die welligt in eene andere gemeente verblijft houdt, de kwijtgescholden som niet derft. Eene rijke grootvader, die de kinderen van zijnen minder bemiddelden zoon, ten zijnent liet wonen, zou dezen laatste, ook al woonde hij tevens te Amsterdam, volgens de bepaling der verordening, die ten deze niet naar het domicilie, maar naar de in- of uitwoning beslist, eene aanzienlijke ontheffing kunnen verschaffen. Men zegge niet: ontduikingen van dien aard, hebben niet plaats gevonden; het is reeds erg genoeg dat zij mogelijk zijn.

De rangschikking dor ingezetenen in klassen, naar mate van hun inkomen, heeft buiten twijfel ook een nadeeligen invloed uitgeoefend. Er zijn een aantal klassen, maar dit neemt niet weg, dat tusschen het belastbare bedrag der verschillende klassen groote verschillen bestaan. De belasting wordt geheven over het minimum van het voor elke klasse aangegeven cijfer. Deze minima verschillen in de hoogste klassen van $\int 300,000$ inkomen en daarboven telkens $f 50,000$. Het verschil tusschen de minima der voorafgaande klassen is geringer en bedraagt van $f 25,000$ tot $f 100,-$, maar daar het inkomen hier ook kleiner is, blijft de speling tusschen de verschillende minima betrekkelijk even aanzienlijk. Voor den belastingschuldige ontstaat hicrdoor eene sterke verleiding om, waar het inkomen den grens aan eene klasse gesteld, naauwelijks overschrijdt, onder dit grenspunt to blijven en op deze wijze over een betrekkelijk niet onbelangrijk bedrag, vrijdom van belasting te erlangen. In de laagste klassen is het versehil zeer gering, doch de verleiding nog grooter doordien inkomen onder $f 600$ geheel vrij is, dat van $f 800$ en daar beneden slechts een vierde, dat van $f 800$ tot $f 1200$ slechts de helft, en dat van $f 1200$ tot $f 2000$ drie v.erde gedeelten der belasting betalen. Door deze regeling wordt niemand naar het juiste bedrag van zijn inkomen belast en het vooropyestelde beginsel eigenlijk geheel verlaten. Afstand werd gedaan van het streven nlar volmaaktheid, want dit brengt mede dat alles worde beproefd om den anslag zooveel mogelijk aan het juiste bedrag van het inkomen te doen naderen. En wat welligt het meest bedenkelijke is, de verleiding tot ontduiking, steeds sterk, werd onwillekeurig bevorderd. Dit alles 
ware te voorkomen door een aanslag naar het inkomen. Dat dit nitvoerbaar zou zijn is niet te betwijfelen. Het beleid van ons dagelijksch bestuur staat borg, dat de bepaling met welwillendheid zou zijn gehandhaafd en waar aan de goede trouw niet was te twijfelen, naar centen of guldens niet zou zijn gevraagd.

Waarom haar dan niet in de verordening opgenomen? De reden ligt voor de hand. Men wenschte op eenmaal niet te veel te vorderen, en liet zich daarbij leiden door een gevoel van billijkheid, dat aan het goed hart van den belastingwetgever alle eer aandoet, maar eene regtvaardige toepassing der belasting wel eenigermate in gevaar stelt.

Er heeft bij den raad zonder twijfel vrees voor openbaarheid bestaan, en eene zekere angst dat een onderzoek naar het juiste bedrag van ieders vermogen een inquisitoriaal karakter zou aannemen. Van daar dat men zich terreden stelde, wanneer een ieder aangaf in welke klasse zijn inkomen was te rangschikken. Zeer gegrond komt mij dit bezwaar niet voor. Alles hangt af van de wijze van uitvoering, die om het even of de eene dan wel de andere wijze van aanslag wordt gevolgd, dragelijk of ondragelijk kan zijn, terwijl het ook weinig verschil maakt dat de weinige ingewijden weten dat iemands inkomen in eene zekere klasse valt doch onbekend zijn met het juiste eijfer, of dat zij ook dit juiste cijfer kennen. Meende men voorts door deze rangschikking de belastingschuldigen minder te stellen tusschen hun beurs en geweten, ik vrees, zooals reeds gezegd, dat wat dit punt betreft, de ervaring de verwachting heeft teleurgesteld.

Een gevoel van billijkheid gaf verder anleiding tot gedeeltelijke ontheffing der lagere klassen. Dit was wederom eene afwijking van het beginsel. Was dit beginsel juist, dan was het tegenover de hoogere klassen minder regtvaardig de lagere minder te belasten, waardoor de eersten ten slotte zwaarder zouden moeten worden getroffen, en de progressie in de lagere klassen eigentlijk slechts. een gevaarlijk antecedent. Het is raadzaam van zeer geringe inkomsten geene belasting te heffen, omdat de kosten van inning betrekkelijk te hoog zijn en getuige de ervaring bij de Pruissische klasseubelasting verkregen van de arbeidende klassen geene directe belasting is te innen, zonder een aantal uitwinningen, die op zich zelve hard zijn en den Staat geen voordeel schenken, daar de opbrengst dikwerf de kosten niet dekt. $\left({ }^{*}\right)$ Daarom is een vrij

$\left(^{*}\right)$ Voor belangrijke bijzonderhedon daaromtrent ase Nenmann, die progrtessive Eiukomntenstener p. $15 \pi$. Vulgens sen berigh der Prnissische reguring waren in 
minimum wensehelijk, dat billijkheidshalve nu het aan ééne klasse van personen is toegestaan, ook aan alle klassen van belastingschuldigen is toe te kennen, door dit vrije bedrag bij iederen aanslag niet in aanmerking te nemen. Vooral ook om het verschil tusschen de laagste klasse en degenen, die vrijgesteld zijn, niet te groot te doen wezen en het gevaar voor ontduiking ook hier wederom te verminderen. Maar verder behoeft men m. i. niet te gaan. $\left({ }^{*}\right)$ Van iederen heffer van inkomsten, die het eenmaal aangenomen minimum overschrijden, kan zonder de billijkheid in eenig opzigt te kort te doen, het volle percentage over het belastbare bedrag worden gevorderd. Burgers van een vrijen staat, die hun pligt beseffen, behooren zoodanige ontheffing niet eens te wenschen. Een duitsch economist acht het eene eer belasting te betalen $(\dagger)$; dit gaat een weinig te ver, doch er ligt iets vernederends in de belasting geheel of gedeeltelijk ongevraagd $\mathrm{kwijtgescholden}$ te ontvangen. Er zou voor dergelijke vrijstelling eenige grond zijn, zoo Amsterdam accijnsen hief. Dan zou, vooral indien de eerste levensbehoeften daarmede waren bezwaard, met regt kunnen worden beweerd, dat de minder bemiddelden daarin een betrekkelijk hooger aandeel dragen dan de rijken en dus door meerdere vrijstelling in de directe belasting schadeloos te stellen ware. $\mathrm{Nu}$ dit echter niet het geval is, ontvalt een der voornaamste gronden voor eene dergelijke regeling.

Er is onder de geleerden veel getwist over de wijze, waarop de aanslag der belastingschuldigen dient te geschieden, of eigen aangifte al of niet dient vooraf te gaan? Eigen aangifte leidt tot ontduiking, aanslag van overheidswege is noodwendig willekeurig. Tegen het eerste bezwaar zijn eenige middelen aantewenden, tegen

de steden van het arrondissement Königsberg in 1871 noodig om th, 100 te innen van de aangeslagenen in klasse 1. a. der klassenbelasting, 797 aanmaningen en 354 uitwinniugen, terwijl 167 dier laatsten vruchtelous bleveu.

(*) De vraag of de belastiugschuldigen regt hebbeu te eischen dat een zeker bedrag worde vrijgelaten, op groud dat dit voor hun noodzakelijk ouderhond vereischt wordt, een zoogen. Existenzminimsm, "warover de natunr zelve bij voorbaat beschikt ", heeft in Duitschland tot een levendigen strijd aanlejling gegeven. Zie hierover o. a. Unpfenbach, Lehrbuch der Finanzwissenschaft, I. p. 121, en vooral, die Stenerfreiheit des Existenzminimums. Ein Beitrag zur Einkommensteuer von Hermann Schmidt (Leipzig, lluucker \& Humblot), waariu de verselillende meeningen ontrent deze vraag zeer uitvoerig worden uagegan.

$(\dagger)$ Wintzingerode in zijn hiervoren aaugehaald Gutachlen ïber Personalhrs/rat. runy. Ougeveer in gelijken geest Dr A. Leld, dit Einkommienstecter.

ECON. 1878, 
het laatste bijna geone, althans niet in een staat, waar de vrijheid op hoogen prijs wordt gesteld, waar een onderzoek van overheidswege naar den finantielen toestand der hurgers niet geduld zou worden. In zooverre is de beslissing $\mathrm{m}$. i. niet moejjelijk. Van twee kwadon is het minst erge te kiezen. De aanslag dient te geschieden naar de aangifte, eene meening, die ook de Amsterdamsche verordening schijnt te zijn toegedaan.

Intusschen werd ook in dit opzigt getransigeerd. Men wilde welwillend zijn en vorderde geen eigen aangifte, waar de belastingschuldige die niet verkoos te doen. Met andere woorden, men liet hem de keus. Ik betwijfel of dit stelsel aanbeveling verdient.

Het opent den belastingschuldige eene kans, die hem ann geen nadeel blootstelt, voor de gemeente echter ongunstig kan uitvallen. Hij kan te hoog of te laag worden anngeslagen. In het eerste geval staat de weg tot reclame hem evenzeer open, als had hị te voren aangifte gedaan; in het laatste is het aan zijn pligtbesef overgelaten, of hij het percentage ovet het bedrag, waarvoor hij te weinig werd angeslagen, in de gemeentekas wil storten dain wel ten eigen bate aanwenden. Dezer dagen werd in de dagbladen melding gemaakt van een paar loffelijke voorbeelden. Een paar personen, wier inkomen ongeveer $f 40.000$ te laag schijnt te zijn geschat, hebben de over dit bedrag verschuldigde som aan den burgemeester toegezonden. Het is te hopen, dat velen, die in hetzelfde geval verkeeren dit voorbeeld zullen volgen, doch men zal mij niet van pessimisme beschuldigen, wanneer ik die hoop zwak noem en voor teleurstelling waarschuw.

De belasting zou naar mijne meening beter aan haar doel beantwoorden, zij zou meert gelijk treffen, zoo eigen aangifte verpligtend wierd voorgeschreven en, zal deze bepaling niet illusoir zijn, eene straf wierd gesteld, niet alleen, zooals thans, op de onvolledigheid der aangiften, maar ook op hare onjuistheid, indien het bewezen wierd, dat deze opzettelijk is geschied en het aangegeven cijfer meer dan bv. 10 pCt. van het werkelijk cijfer verschilt. De gemeentewet straft ontduiking of overtreding ter zake van plaatselijke belasting, de poging daartoe of de medepligtigheid daaraan met eene hoete van het dubbele van het verschuldigde bedrag, doch tot dusverre is eene onjuiste opgave noch als ontduiking noch als verzuim van behoorlijke invulling van het beschrijvingsbillet beschouwd. Nadat de aangifte verpligtend ware gesteld, zou het wenschelijk zijn van deze gedragslijn aftewijken, zoo noodig een daartoe strekkende strafbepaling in de verordening optenemen en de belastingschul- 
digen in het heschrijvingsbillet daaraan te herinneren. In Oostenrịjk bedraagt het regt ingeval van ontduiking het driedubbele $\left({ }^{*}\right)$, in Engeland is op opzettelijk onjuiste opgaven eene straf gesteld van driemaal het regt over het niet aangegeven bedrag. ( $\dagger$ ) Strenge strafbepalingen zijn noodig; zelfs al worden zij zelden toegepast, werken zij heilzaam, voor zooverre zij opzettelijk onjuiste opgaven voorkomen. Men is te Amsterdam tegenover degenen, die willens en wetens de verordening overtreden, veel te welwillend, noch welwillender dan te Sparta. Daar werd althans ingeval van ontdekking straf toegepast; hier geschiedt het voorloopig in geen geval. Ontduiking is zeer zeker ook hier niet geoorloofd, maar is zij gepleegd, de schuldige kan zeker wezen te zijn gevrijwaard voor straf en zelfs rekenen op geheimhouding.

Hoe meer men de verordening in haar geheel beschouwt, hoe meer men onwillekeurig tot het vermoeden komt, dat haar ontwerper veel gevoelde voor de bezwaren tegen de inkomstenbelasting en haar slechts noode aanbeval. Aan elken grief wordt tegemoet komen, elk bezwaar wordt ontzien, alsof de belasting in het leven wierd geroepen ten behoeve der belastingschuldigen en op humne wenschen in de eerste plaats ware te letten. Dit gaat zelfs zoover, dat waar de gemeentewet bepaalt, dat de kohieren roor een ieder ter lezing worden nedergelegd, een ieder slechts inzage van zijn eigen aanslag wordt vergund. De contrôle, die de gemeentewet in openbaarheid zag, werd gering geacht, het bezwaar van enkele belastingsehuldigen, die op geheimhouding aandrongen, overwegend. Ik zal onnoodige strenge fiscale maatregelen niet verdedigen noch aanprijzen, maar de fiscus heeft ook regten en het algemeen belang vordert evenzeer handhaving van deze als van die der burgers. Er heerseht in de verordening eene welwillendheid, die aan zwakheid grenst, waardoor het beginsel voortdurend wordt prijsgegeven en ten slotte onkenbaar wordt. Zoodanige wetten kunnen onmogelijk goed werken.

Wanneer men buiten Amsterdam mogt vragen, waarom de uitkomst der belasting in vele opzigten beneden de verwachting is gebleven, dan geloof ik dat het vorenstaande tot antwoord zou kunnen dienen. Eenigen zullen mij beschuldigen van over-

(*) Leroy-Bealieu. Traité de la science des finances I. p. 462 .

(t) 5 en 6 Vict. c. 35 s. 127 . Tie vok 16 en 17 Vict. c. 34 s. 50: Pritl's Income tax acts, etc. by J, Paterson, 3e ed, [1, 70 en 129. 
drijuing, ik hel, hier en daar welligt schelle kleuren gebezigd om het beeld sterk in het oog te doen springen, maar niet zou het mij verwonderen indien degenen, die meer dan $i k$ in de gelegenheid waren, de werking der belasting van nabij nategaan, verklaarden, dat ik beneden de werkelijkheid ben gebleven. Hoe dit echter zij, mijn doel zal zijn bereikt, zoo dit geschrift aanleiding mogt geven tot eene herziening der belasting. De eerste invoering was uiterst moeijelijk. Thans heeft de ervaring ons reels veel geleerd, en het is pligt zich die ten nutte te maken, vooral nu eene stijging der uitgaven in het versehiet is. Al heeft de gemeenteraad ook het regt, het percentage zoo hoog op te voeren, als hij noodig acht, het is niet te betwisten, dat hoe hooger het percentage is, des te sterker het gevaar van ontduiking zal zijn, en dat het streven behoort te wezen eene zoo hoog mogelijke som van het gezamenlijk inkomen, waarover de belasting geheven wordt, te verkrijgen. In dit opzigt kan naar ik meen nog veel worden gedaan, doch, daarvan zij men overtuigd, wat ook uit mijne pen moge zijn gevloeid, dat niemand meer dan ik beamen zal den spreuk, dat gemakkelijk is de critiek en moeijelijk de kunst.
Amsterdam, 5 Februarij 1878.
F. S. van Nierop.

Naselurift. Nadat dit opschrift reeds ter perse was gezonden, werd door Burg. en Weth, aan den raad eene voordragt ingediend, strekkende tot het brengen van eenige wijzigingen in de verordening. Hoezeer eene diepingrijpende verandering door het dagelijksch bestuur niet noodig wordt geacht, zoo blijkt toch uit het voorstel, dat eenige door mij gewraakte bepalingen inderdaad ongunstig hebben gewerkt.

Dit gellt in de eerste plaats van al. $d$. van art. 7 .

${ }_{n}$ Deze, zoo verklaren Burg. en Weth., heeft in de praktijk vele bezwaren opgeleverd, aangezien onderscheidene belastingschuldigen geneigd zijn een aantal zaken als "toevallige baten" aantemerken en niel. bij hunne inkomsten te berekenen, die daaronder naar onze meening wel degelijk moeten rooriten en althans bij de vaststelling der verordening daaronder zijm bedoeld."

$Z_{\mathrm{ij}}$ stellen mitsdien voor deze alinea to vervangen door twee nieuwe van den navolgenden inhoud: 
„Baten uit loterijen, erfenisson, legaten en schenkingen worden niet als inkomen aangemerkt, tenzij de legaten bestaan in jaarlijksche nitkeeringen en de schenkingen in giften van hand tot hand of in jaarlijksche uitkeeringen ontvangen van personen, die clders wonende, niet in deze belasting bijdragen.

„De renten uit dergelijke baten verkregen worden steeds geacht tot het inkomen te behooren.

De jaarlijksehe uitkeeringen of giften door bloed- of annverwanten in de regte lijn genoten, worden steeds onder het inkomen van don begiftigde en niet onder dat van den gever berekend."

De wijziging is ongetwijfeld eene verbetering. Of zij echter bovredigend is, blijft $\mathrm{m}$. i. te betwijfelen. Zoo de bloed- of anverwant in de regte lijn belastingschuldig is wegens genoten giften, lan zou de consequentie vorderen, dat een ieder, die een gift ontving, vooral indien deze in een jaarlijksche uitkeering bestond, daarover belasting betaalde. Intusschen wordt voorgesteld giften ontvangen van personen, met wien de begiftigde in de regte lijn niet verwant is, niet als inkomen is antemerken, tenzij de schenker elders woont.

Voor deze onderscheidingen bestaat naar mijne meening geen grond. Ik ga zelfs verder en meen dat de vrijstelling van giften van hand tot hand grelreei behoort te vervallen.

De fiseus heeft niet te vragen hoe het inkomen verkregen wordt, noch waartoe het wordt aangewend. De begiftigde heeft geen regt vrijdom te vorderen. Hij, die zonder inspanning inkomen erlangt, kan zeer zeker den fiscus diens deel afstaan, veel beter dan degeen, die door arbeid zijn inkomen verwerft.

De schenker heeft evenmin grond vrijstelling to eischen. De omstandigheid dat hij het bedrag niet ten eigen bate heeft aangewend maar aan derden afgestaan, is den fiscus onverschillig. Bij de inkomstenbelasting heeft men niet te onderzoeken naar het gebruik van het inkomen, maar zelfs zoo dit ware te doen, zou eer het bedrag aangewend tot eigen levensonderhoud op vrijdom mogen aanspraak maken, dan hetgeen vrijwillig aan anderen is geschonken.

Men zegge niet dat op deze wijze tweemaal belasting zou worden gevorderd over het zelfde bedrag, eerst bij den gever, dal bij den begiftigde. Dit doet niets ter zake en geschiodt voortdurend, waar geen giften zijn verstrekt, waar het inkomen is verkregen door diensten, die de arbeidgevers gewoon zijn uit hun inkomen te hetalen. Wenscht men cen voorbeold uit velen, men 
neme een arts, wiens inkomen verkregen wordt uit het inkomen zijner patienten. Deze betalen over het bedrag, dat zij aan den arts geven, de belasting, en de arts doet het nogmaals. Zoo zoudeu cen aantal voorbeelden zijn te verstrekken, zoo het noodig ware te bewijzen, dat de bedenking, dat dezelfde som niet twee of meermalen mag worden belast, geen grond hoegenaamd bezit. Ieder persoon heeft een zelfstandig inkomen en al wordt dit der begiftigden dikwerf niet als een oorspronkelijk, maar als een afgeleid inkomen beschouwd, ik zie, na het zoo even gezegde, daarin geen voldoende reden om hun vrijdom te geven.

De Amsterdamsche wetgever zou door eene onderscheiding, als wordt voorgesteld, in de verordening op te nemen een gevaarlijk antecedent in het leven roepen. Hij vergete niet dat de som der gezamenlijke inkomsten belaugrijk grooter is dan het maatschappelijk inkomen en dat waar naar den oorsprong van het inkomen door arbeid verkregen, geen onderzoek wordt gedaan, het niet billijk is tegenover de overige belastingschuldigen, bij inkomsten zonder eenige inspanning verworven wegens den oorsprong vrijstelling te verleenen.

De twoede der voorgestelde wijzigingen betreft de classificatie. „De ondervinding, dus zeggen Burg. en Weth., heeft doen zien lat een onevenredig groot aantal belastingschuldigen zich in de zesde klasse $\left(\int 1500\right.$ tot $\left.f 2000\right)$ aangeeft en hun aanslag derhalve over $\int 1500$ wordt berekend." Om dit te voorkomen wordt voorgesteld de klassen met één te vermeerderen, in klasse $5 a$ optenemen inkomen van $f 1200$ tot beneden $f 1400$, in klasse $5 b$ inkomen van $f 1400$ tot beneden $f 1700$, en in klasse 6 inkomen van $f 1700$ tot beneden $\int 2000$. Het blijft te betwijfelen of deze wijziging veel vrucht zal dragen. De oorzaak van het kwaad, dat men te keer wenscht te gaan, ligt in de classificatie zelve en niet het minst in de nog daarbij komende omstandigheid dat van inkomens onder $f 2000$ slechts $\frac{3}{4}$ van het percentage wordt gevorderd. 